\title{
Efficacy and Estimated Annual Cost of Common Weed Control Methods in Landscape Planting Beds
}

\author{
S. Christopher Marble ${ }^{1,4}$, Andrew K. Koeser ${ }^{2}$, Gitta Hasing ${ }^{2}$, \\ Drew McClean ${ }^{2}$, and Annette Chandler ${ }^{3}$
}

ADDITIONAL INDEX WORDS. herbicides, homeowner, horticulture, preemergence, mulch, maintenance, ornamental

\begin{abstract}
Summary. Organic mulch is commonly used in landscape planting beds to improve plant growth and reduce competition from weed species. Although many different mulch materials have been evaluated in landscape, forestry, or agricultural settings, there have been no previous reports concerning the maintenance costs associated with different mulch materials from a weed control perspective. Trials were conducted at two locations in Florida to estimate the annual maintenance costs associated with pine bark nuggets (bark derived from pine species not specified) and pine straw mulch [mix of longleaf pine (Pinus palustris) and slash pine (Pinus taeda) needles] with and without the use of a granular preemergence herbicide when maintained at similar depths in schilling's holly (Ilex vomitoria 'Schilling's Dwarf') shrub beds and asiatic jasmine (Trachelospermum asiaticum 'Minima') groundcover beds. Weed coverage and residual mulch depth were tracked over time, with maximum and minimum thresholds ( $20 \%$ and 2 inches, respectively) set as triggers for maintenance activities. Results showed that the addition of herbicide (trifluralin + isoxaben) had little to no impact on weeding frequency or time when plots were mulched, but did reduce hand weeding frequency and time compared with nontreated, nonmulched plots. Both mulch materials used alone reduced hand weeding frequency and time compared with herbicide-only treatments. Although results varied by bed type and location, pine bark generally provided greater weed control compared with pine straw and required fewer mulch additions and less mulch by volume. Results from this study suggests that using pine bark nuggets as mulch may result in lower maintenance costs and weed pressure compared with pine straw when both are applied and maintained at 2 -inch depths.
\end{abstract}

$\mathrm{M}$ any studies have analyzed the benefits and disadvantages of common weed control techniques in urban or suburban landscape settings as they pertain to weed control. In most cases, homeowners or landscapers will use mulch (organic or inorganic), geotextile fabric, herbicides, or a combination of these methods to control weeds (Marble et al., 2015a, 2015b).

We thank the University of Florida Center for Landscape Conservation and Ecology for financial support and gratefully acknowledge the statistical expertise provided by Edzard van Santen of the University of Florida Institute of Food and Agricultural Sciences Statistical Consulting Unit

${ }^{1}$ Department of Environmental Horticulture, University of Florida, Mid-Florida Research and Education Center, 2725 South Binion Road, Apopka, FL 32703

${ }^{2}$ Department of Environmental Horticulture, University of Florida Gulf Coast Research and Education Center, 14625 County Road 672, Wimauma, FL 33598

${ }^{3}$ University of Florida Mid-Florida Research and Education Center, 2725 South Binion Road, Apopka, FL 32703

${ }^{4}$ Corresponding author. E-mail: marblesc@ufl.edu.

doi: 10.21273/HORTTECH03609-16
In addition to improving plant growth (Greenly and Rakow, 1995), organic mulches have been shown to reduce weed seed germination (Cochran et al., 2009; Richardson et al., 2008) through light exclusion, reduction of available water for weed seeds, allelopathy, and by acting as a barrier to emerging seedlings (Chalker-Scott, 2007). The exact method in which mulches reduce weed growth is not known for all mulch types, but light exclusion has been attributed as being the most common method (Teasdale and
Mohler, 2000) as most weed seeds require light to germinate (Wesson and Wareing, 1967). Although many organic materials can exclude light if applied at sufficient depth, they degrade over time and certain materials potentially attract unwanted pests (Duryea et al., 1999a, 1999b; Gill et al., 2011). Inorganic mulches (gravel/stone) will not degrade but are associated with higher upfront installation costs and do not improve soil quality. Multiple geotextile fabrics have been evaluated, and research suggests most are only effective for a short time and have little efficacy on perennial weed species (Appleton and Derr, 1989; Martin et al., 1987). Landscape fabrics are designed to be installed at the time of planting, and proper installation in an existing landscape is very difficult. The use of landscape fabric also requires mulch to be applied over the material for aesthetic purposes, further increasing cost. Over time, weeds can root through the fabric, making hand weeding difficult and more time consuming compared with areas in which no fabric was used (Horowitz, 1993). A comprehensive review of the advantages and disadvantages of most of the more prevalent mulch materials was previously published by ChalkerScott (2007), and a review of nonchemical weed control methods was recently published by Marble et al. (2015a). Both authors concluded that organic or inorganic mulch was a very effective weed control tool if applied at a proper depth.

In addition to mulch materials, herbicides are commonly used in urban and suburban landscapes, either broadcast over the entire area (preemergence herbicides) or spot applied/directed (postemergence herbicides). Research on the various active ingredients evaluated for weed control in planting beds has been reviewed previously (Marble et al.,

\begin{tabular}{llll}
\hline $\begin{array}{l}\text { Units } \\
\text { To convert U.S. to SI, } \\
\text { multiply by }\end{array}$ & U.S. unit & SI unit & $\begin{array}{l}\text { To convert SI to U.S., } \\
\text { multiply by }\end{array}$ \\
\hline 0.3048 & $\mathrm{ft}$ & $\mathrm{m}$ & 3.2808 \\
0.0929 & $\mathrm{ft}^{2}$ & $\mathrm{~m}^{2}$ & 10.7639 \\
28.3168 & $\mathrm{ft}^{3}$ & $\mathrm{~L}$ & 0.0353 \\
3.7854 & $\mathrm{gal}$ & $\mathrm{L}$ & 0.2642 \\
2.54 & inch(es) & $\mathrm{cm}$ & 0.3937 \\
1.1209 & lb/acre & $\mathrm{kg} \cdot \mathrm{ha}^{-1}$ & 0.8922 \\
28.3495 & $\mathrm{Oz}$ & $\mathrm{g}$ & 0.0353 \\
$\left({ }^{\circ} \mathrm{F}-32\right) \div 1.8$ & ${ }^{\circ} \mathrm{F}$ & ${ }^{\circ} \mathrm{C}$ & $\left({ }^{\circ} \mathrm{C} \times 1.8\right)+32$ \\
& & & \\
\end{tabular}


$2015 b)$. Similarly, the body of research pertaining to herbicide and mulch interactions and combinations has been summarized and synthesized (Marble, 2015). Overall, the bulk of the research suggests that the best herbicide-mulch combination, from an efficacy standpoint, will largely depend on mulch depth and weed species present, with herbicide active ingredient and rate becoming less significant as mulch depth increases (Marble, 2015).

Although many different strategies have been thoroughly evaluated for landscape weed control efficacy, research is lacking on which method or combination of methods is most economical on a yearly basis. This is one of the most common questions raised by both homeowners and professional landscape contractors (S.C. Marble, unpublished data). Mulch degradation has been previously tracked over time (Duryea et al., 1999a, 1999b), and the materials that degrade more quickly (e.g., pine straw) are often the least costly. Additionally, if mulch were consistently maintained at an adequate depth, it is unknown if the addition of an herbicide would be needed or would further reduce costs. Following an extensive review of the literature (Marble et al., 2015a, 2015b), to our knowledge there have been no previous reports of the estimated annual cost of common weed control methods in landscape planting beds. Therefore, the objective of this study is to evaluate common methods of weed control in landscape planting beds in terms of both efficacy and total cost on an annual basis and to evaluate if the use of preemergence herbicides significantly impacted total maintenance costs in mulched and unmulched beds.

\section{Materials and methods}

Research trials were conducted in Apopka and Balm, FL, from Sept. 2014 to Sept. 2015. At both locations, 72 landscape beds $(5 \times 5 \mathrm{ft})$ were constructed using pressure treated wooden boards ( 2 inches thick and 6 inches wide) placed on the perimeter of each bed and held together using wood screws. On 9 Sept. 2014, a shrub species (schilling's holly or holly) and a groundcover species (asiatic jasmine) (both obtained from Harrell's Nursery,
Plant City, FL) were transplanted from no. 3 (3 gal) and trade gallon $(0.7 \mathrm{gal})$ containers, respectively, into prepared landscape beds in Balm, FL, containing a sandy soil $(2.2 \%$ organic matter, $\mathrm{pH}$ 7.2). On 23 Sept., a second trial was implemented with the same plant species transplanted into landscape beds in Apopka, FL, containing a sandy soil ( $1 \%$ organic matter, $\mathrm{pH}$ 6.2).

At each site, beds were planted with either two holly or three asiatic jasmine plants spaced $2 \mathrm{ft}$ apart based on standard industry practices and were watered in by hand. Plots were made weed free before planting and weed control treatments (Table 1) began on 11 Sept. and 25 Sept. for the Balm and Apopka sites, respectively. Treatments consisted of longleaf pine straw alone (pine straw needles), pine bark nuggets alone (Timberline Mulch; Oldcastle ${ }^{\circledR}$, Atlanta, GA) (pine bark), herbicide alone (herbicide), pine straw with herbicide (pine straw + herbicide), pine bark with herbicide (pine bark + herbicide), and a bare soil control treatment (control). Each mulch material was applied at a depth of 2 inches using the wooden boards that framed the beds to prevent mulch materials from blowing or washing out of the experimental plots. For treatments requiring an herbicide application, trifluralin + isoxaben (Snapshot $^{\circledR} 2.5 \mathrm{G}$; Dow AgroSciences, Indianapolis, IN) was applied using a hand-shaker jar at the highest recommended label rate $(5 \mathrm{lb} /$ acre a.i.) following mulch application. After all treatments were applied, 0.5 inches of irrigation was applied to all plots using portable overhead sprinklers to activate the herbicide. After this initial watering, drip irrigation was used thereafter to water plants as needed when rainfall was not adequate (Figs. 1 and 2). Additionally, plants were fertilized by broadcasting $2.5 \mathrm{oz}$ of fertilizer [Osmocote ${ }^{\circledR}$ Plus $15 \mathrm{~N}-$ 3.9P-10K (4 months); Everris Intl., Geldermalsen, The Netherlands] to each plot every 4 months throughout the project based on manufacturer recommendations and soil test results.

Weed coverage data (visual rating scale from 0 to $100,0=$ no weeds, $100=$ complete weed coverage), weed species, and mulch depth measurements were taken biweekly for $\mathbf{5 2}$ weeks at each location using natural weed populations at both locations. As aesthetic thresholds can vary widely depending on personal preferences, visibility, location, and many other factors which are difficult to predict, we chose a $20 \%$ coverage rating as an estimate of the maximum weed coverage aesthetically acceptable before action would be required in most landscapes based on our experience. When weed coverage ratings exceeded $20 \%$ in any plot, plots were weeded by hand to remove all weeds and time needed to hand weed each plot was recorded.

Mulch depth measurements were taken by randomly selecting three locations in each plot and inserting a ruler through the top of the mulch to the soil surface. When average mulch depth dropped below 2 inches in any experimental plot, mulch was added by hand and depth was again measured until an average depth of 2 inches was reached. The amount of mulch material added was recorded by volume.

As appropriate for treatments involving herbicide, herbicide was applied every 4 months so that the manufacturer's maximum annual usage rate ( $15 \mathrm{lb} /$ acre a.i.) was not exceeded (11 Sept. 2014, 14 Jan. 2015, and 11 May 2015 in Balm; 25 Sept. 2014, 29 Jan. 2015, and 21 May 2015 in Apopka). For plots receiving an herbicide treatment, plots were hand weeded before application (and time recorded) and watered in the manner described above after each application.

Uniform soil characteristics and maintenance history allowed for a completely randomized design in Balm, while a completely randomized block design was used in Apopka due to higher weed pressure being observed in portions of the experimental site before tilling and study initiation (previously fallow). Each treatment combination was replicated six times at each location for each bed type [asiatic jasmine (groundcover) or holly (shrub)]. Data were collected biweekly in each location for 52 weeks in Balm (19 Sept. 2014 to 9 Sept. 2015 ) and Apopka (9 Oct. 2014 to 7 Oct. 2015). Percent weed coverage and mulching depth were treated as indicator variables that determined management actions (hand weeding or mulch addition) that needed to be 
Table 1. Installation (labor + material) cost of common weed control methods in landscape planting beds. ${ }^{\mathrm{z}}$

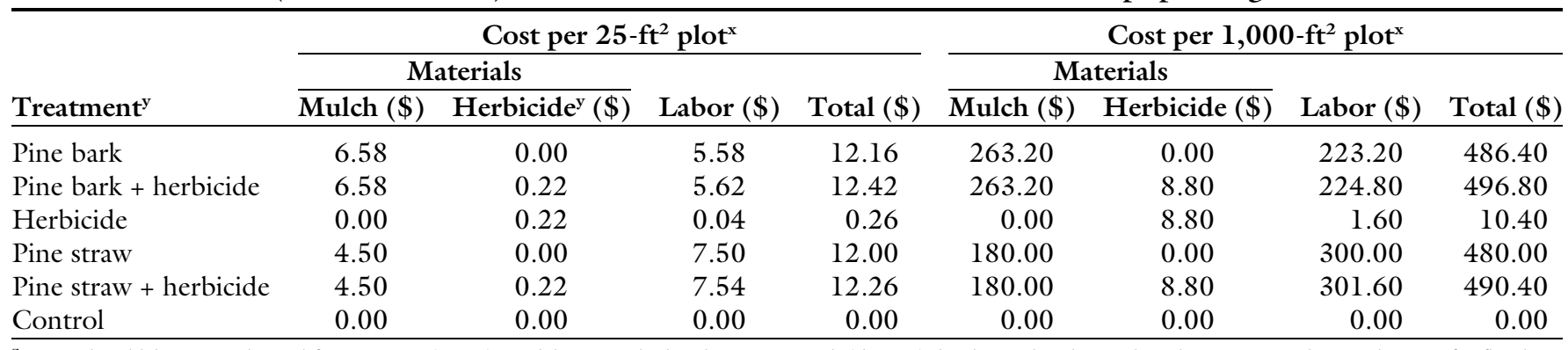

${ }^{\mathrm{z}}$ Material and labor costs derived from Fortier (2014). Mulch costs calculated using a 2 -inch $(5.1 \mathrm{~cm})$ depth. Herbicide cost based on average advertised price of trifluralin + isoxaben applied at $5 \mathrm{lb} /$ acre $\left(5.6 \mathrm{~kg} \cdot \mathrm{ha}^{-1}\right)$ a.i.

${ }^{\mathrm{y}}$ Pine bark = pine bark nuggets $(2$-inch depth $)$; pine straw $=$ pine straw [ mix of longleaf and slash pine needles $(2$-inch depth $\left.)\right]$, herbicide $=$ trifluralin + isoxaben applied at 5 lb $/$ acre a.i. at 4 -mo. intervals.

${ }^{\mathrm{x}} \$ 1.00 / 25 \mathrm{ft}^{2}\left(2.3 \mathrm{~m}^{2}\right)=\$ 0.4306 / \mathrm{m}^{2}, \$ 1.00 / 1000 \mathrm{ft}^{2}\left(92.9 \mathrm{~m}^{2}\right)=\$ 0.0108 / \mathrm{m}^{2}$.

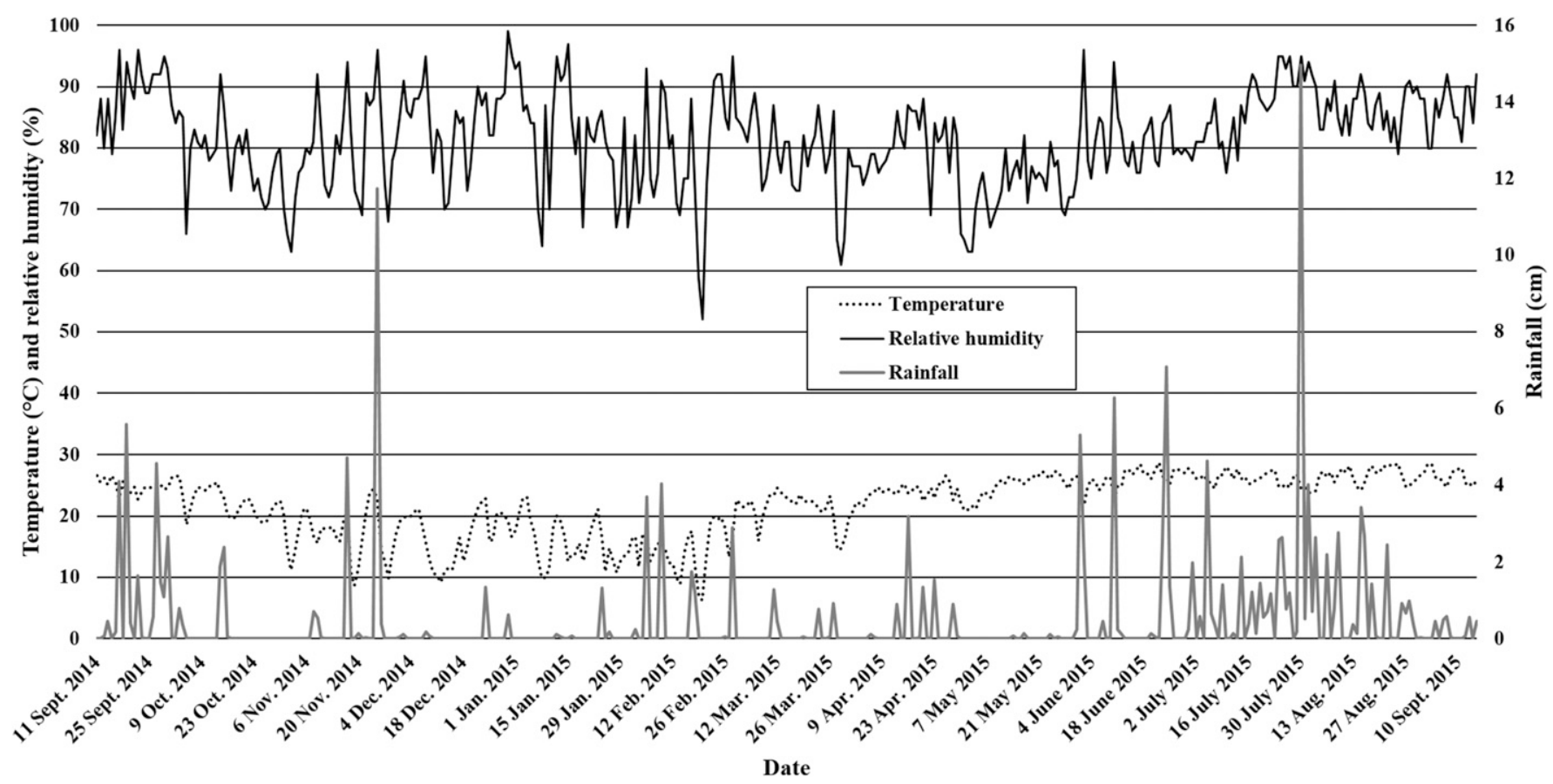

Fig. 1. Average daily temperature, relative humidity, and total daily rainfall recorded during the experiment in Balm, FL, to determine annual maintenance costs associated with weed control in landscape planting beds mulched with pine bark or pine straw (mix of longleaf and slash pine needles) with and without the use of herbicide (trifluralin + isoxaben); $\left(1.8 \times{ }^{\circ} \mathrm{C}\right)+32=$ ${ }^{\circ} \mathrm{F}, 1 \mathrm{~cm}=0.3937$ inch.

taken. Frequency of weeding action and mulch addition (with $0=$ no action, $\mathrm{l}=$ action needed) based on percent weed coverage and mulch depth indicator variables was analyzed using a generalized linear mixed model (PROC GLIMMIX, SAS ${ }^{\circledR}$ version 9.4; $\mathrm{SAS}^{\circledR}$ Institute, Cary, NC) (Littell et al., 2006) using binomial distribution and the inverse link function was used to transform mean frequencies from a logarithm to the original data scale (Littell et al., 2006). Weeding time, mulch amount, and mulch time were analyzed using linear mixed models
(PROC MIXED, SAS ${ }^{\circledR}$ version 9.4) and all pairwise comparisons were completed using the Tukey's honestly significant difference test. Weed percent coverage was analyzed biweekly using the same approach, and due to a lack of consistency in weed species prevalence throughout experiment plots, weed coverage was analyzed as total weed coverage of all species present. Contrasts between fixed effects of mulch type and herbicide use were made using LSMESTIMATE statements in AAS $^{\circledR}$ version 9.4. In all cases, LS means were reported and differences considered significant at $P \leq$
0.05. Linear correlations were determined for the effects of weed coverage on weeding time using the Proc CORR procedure $\left(\right.$ SAS $^{\circledR}$ version 9.4). Weather data were obtained from the Florida Automated Weather Network (FAWN, 2016) weather stations, which were housed on-site at each location. Average daily air temperature, relative humidity, rainfall, and solar radiation were averaged over 2 -week periods coinciding with trial data collection dates. Linear regression was then used to determine the relationship between weed coverage and weeding time with the environmental 


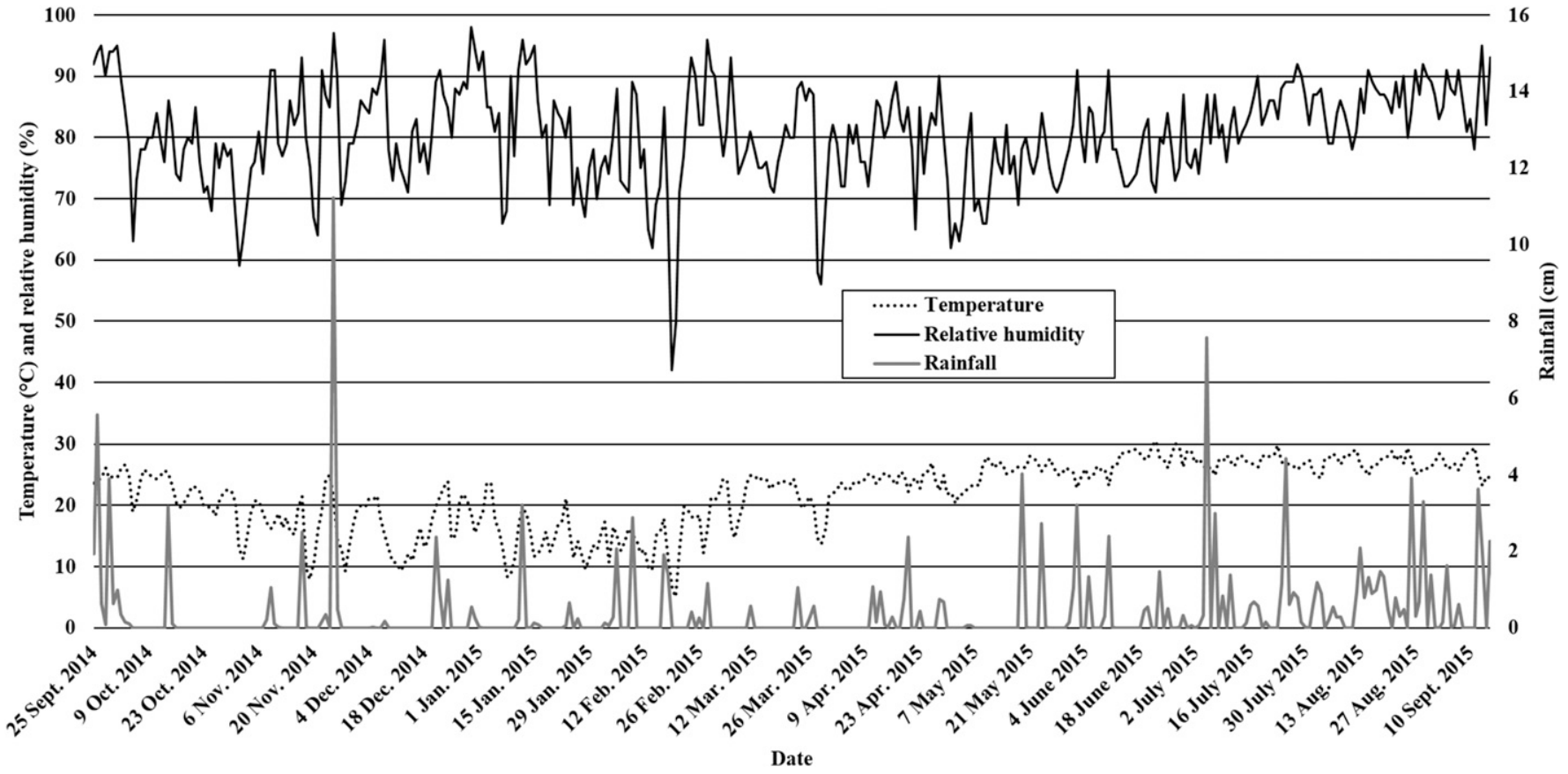

Fig. 2. Average daily temperature, relative humidity, and total daily rainfall recorded during the experiment in Apopka, FL, to determine annual maintenance costs associated with weed control in landscape planting beds mulched with pine bark or pine straw (mix of longleaf and slash pine needles) with and without the use of herbicide (trifluralin + isoxaben); $\left(1.8 \times{ }^{\circ} \mathrm{C}\right)+32=$ ${ }^{\circ} \mathrm{F}, 1 \mathrm{~cm}=0.3937$ inch.

conditions mentioned above during the trial period at each location, first overall and then within each weed control treatment. Where costs are estimated, installation (Table 1), labor, and material cost estimates were calculated using national averages reported by Fortier (2014) and data were collected for weeding times and mulching (amount and time). Herbicide cost estimates were calculated using the average advertised price of 10 online retailers after omitting shipping costs. All costs are reported on a perplot or $25-\mathrm{ft}^{2}$ basis, except where noted.

\section{Results}

Weeding time and percent weed coverage were positively correlated in both $\operatorname{Balm}\left(R^{2}=0.67, P<0.001\right)$ and Apopka $\left(R^{2}=0.46, P<0.001\right)$ overall treatments and bed types, and correlations remained significant when examining relationships within each individual treatment (data not shown). Regression analysis showed that air temperature, relative humidity, rainfall, and solar radiation were all poor predictors of weed coverage and weeding time at both locations and within all treatments. Few differences were noted in plant growth among the different weed control treatments in either location. There were no differences in plant growth in either species among any of the treatments in Apopka at trial conclusion. In Balm, holly in all weed control treatments were similar in size to nontreated controls. Asiatic jasmine in pine bark plots were slightly larger in size than those in control, herbicide, or straw + herbicide treatments but differences in growth could not be discerned visually (data not shown).

WeEd COVERAgE. In Balm, no weed species predominated plots, but on most dates the most common weeds observed included spanish needle (Bidens alba), tasselflower (Emilia fosbergii), hyssop spurge (Chamaesyce byssopifolia), natalgrass (Melinis repens), chamberbitter (Phyllanthus urinaria), and paraguayan purslane (Portulaca amilis). These species are predominately warm-season annuals, but a warm winter and overall mild conditions (Figs. 1 and 2) facilitated germination of these species throughout most of the trial period. For both shrub and groundcover beds, control and herbicide treatments generally had the highest mean weed coverage on most data collection dates, and pine bark + herbicide plots generally had the lowest (Figs. 3 and 4). Mean weed coverage ratings of over $60 \%$ were observed in groundcover plots at the Balm site in early January, likely due to a brief period of warmer weather and higher than expected rainfall (Figs. 1 and 4). The second herbicide application made to shrub beds in January resulted in the herbicide treatment having the lowest weed coverage of any treatment at the Balm site for $\approx 4$ weeks (Fig. 3). The application made in May resulted in less of an impact in terms of weed coverage differences between the herbicide and various herbicide + mulch treatments. In general, the herbicide treatments had less of an impact in groundcover beds at the Balm site. The herbicide treatment generally had similar or greater weed coverage than for mulch and mulch + herbicide applications during the evaluation period following the application. Overall, the mulch treatments showed little response to herbicide application in terms of increased weed control, and weed coverage ratings tended to remain consistent between mulch treatments with or without the use of herbicide.

Similar to Balm, there were no predominate or consistent weed populations throughout the Apopka 


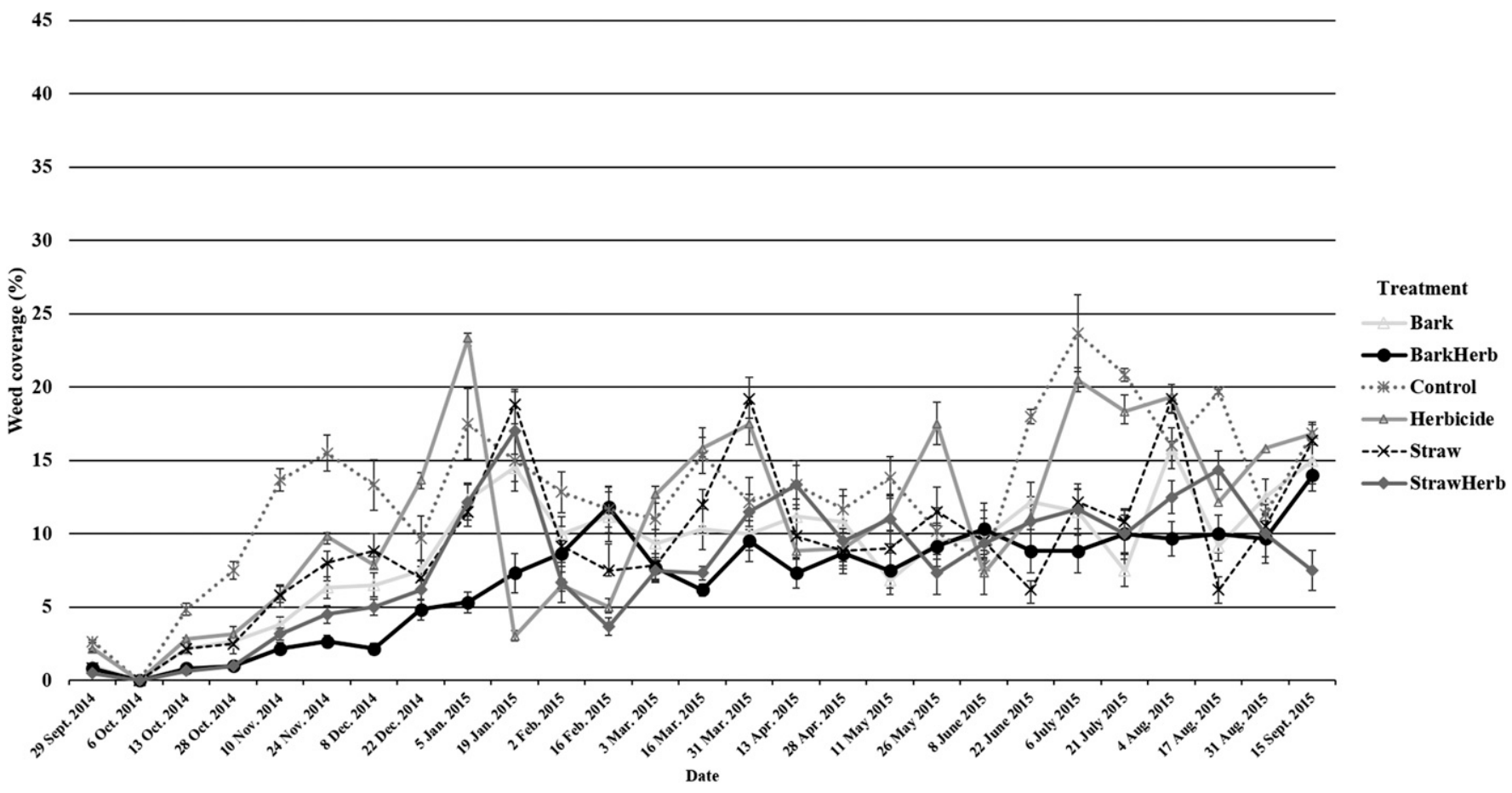

Fig. 3. Biweekly percent coverage ratings in Balm, FL, shrub (schilling's holly) planting beds. Means and associated SE are shown. Pine bark = pine bark nuggets $[2$-inch $(5.1 \mathrm{~cm})$ depth], pine straw $=$ pine straw [ $\mathrm{mix}$ of longleaf and slash pine needles $(2$-inch depth) ], herbicide = trifluralin + isoxaben applied on 10 Sept. 2014, and 14 Jan., and 11 May 2015 using the highest recommended label rate $\left[5 \mathrm{lb} /\right.$ acre $\left(5.6 \mathrm{~kg} \cdot \mathrm{ha}^{-1}\right)$ a.i. $]$, BarkHerb $=$ pine bark + herbicide, $=$ pine straw + herbicide.

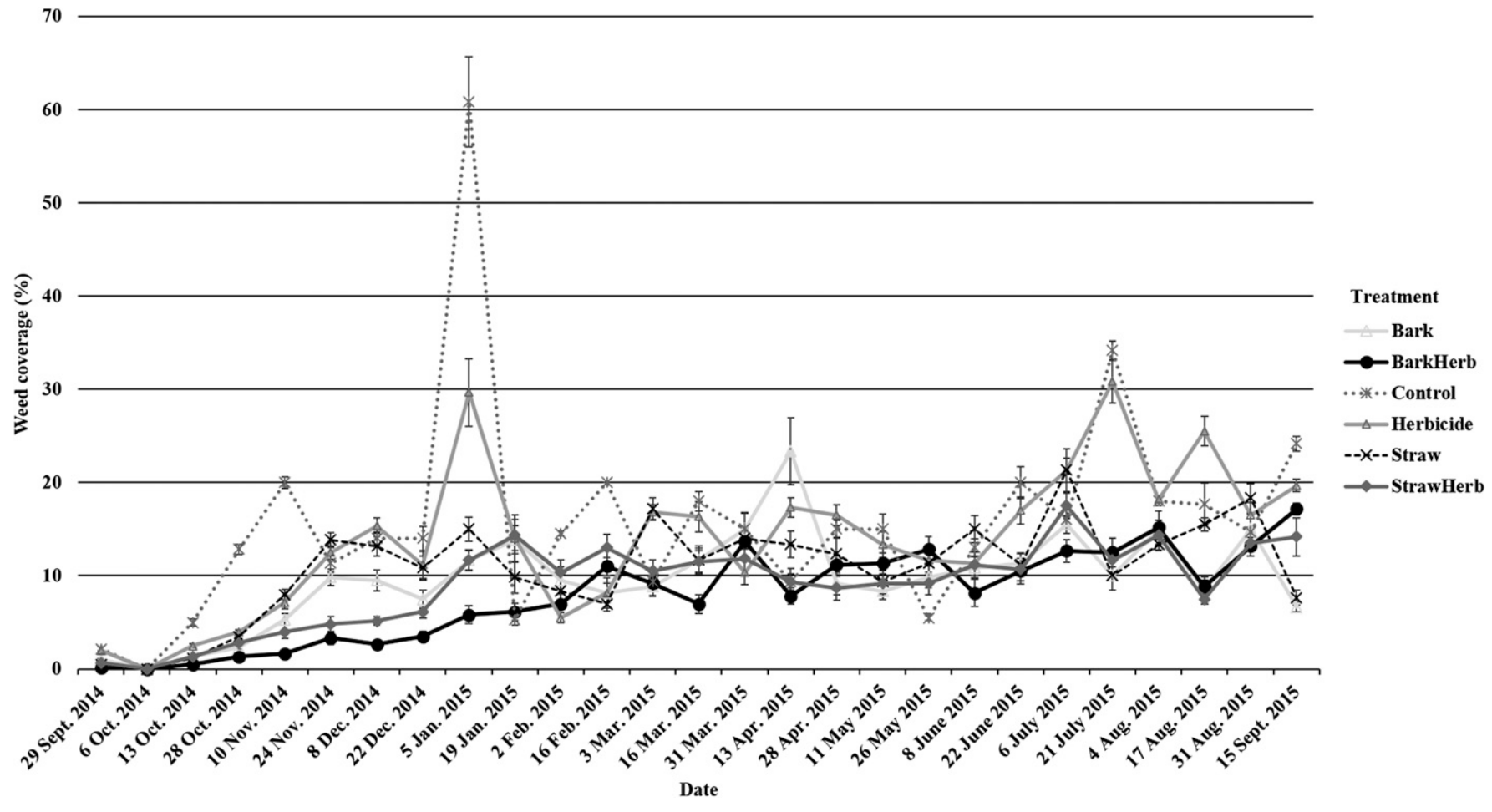

Fig. 4. Biweekly percent coverage ratings in Balm, FL, groundcover (asiatic jasmine) planting beds. Means and associated SE are shown. Pine bark = pine bark nuggets [2-inch $(5.1 \mathrm{~cm})$ depth], pine straw = pine straw [mix of longleaf and slash pine needles (2-inch depth) ], herbicide $=$ trifluralin + isoxaben applied on 10 Sept. 2014, and 14 Jan., and 11 May 2015 using the highest recommended label rate $\left[5 \mathrm{lb} /\right.$ acre $\left(5.6 \mathrm{~kg} \cdot \mathrm{ha}^{-1}\right)$ a.i. $]$, bark herb $=$ pine bark + herbicide, straw herb $=$ pine straw + herbicide. 


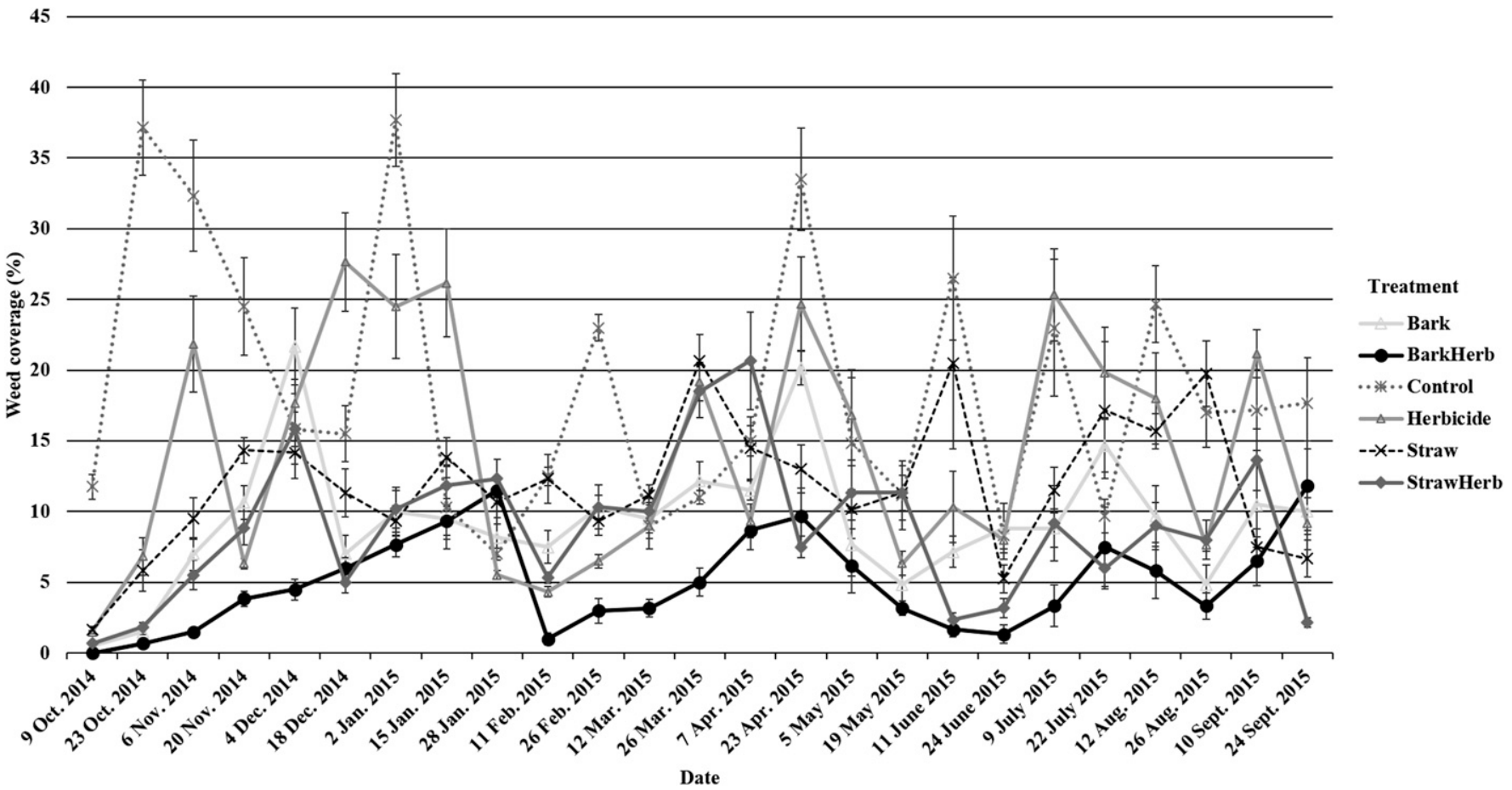

Fig. 5. Biweekly percent coverage ratings in Apopka, FL, shrub (schilling's holly) planting beds. Means and associated standard errors are shown. Pine bark = pine bark nuggets [2-inch $(5.1 \mathrm{~cm})$ depth], pine straw = pine straw [ $\mathrm{mix}$ of longleaf and slash pine needles $(2$-inch depth $)]$, herbicide $=$ trifluralin + isoxaben applied on 10 Sept. 2014, and 14 Jan., and 11 May 2015 using the highest recommended label rate $\left[5 \mathrm{lb} /\right.$ acre $\left(5.6 \mathrm{~kg} \cdot \mathrm{ha}^{-1}\right)$ a.i. $]$, bark herb $=$ pine bark + herbicide, straw herb $=$ pine straw + herbicide.

experimental site. The most common weed species observed included spotted spurge (Chamaesyce maculata), tropical mexican clover (Richardia brasiliensis), florida pusley ( $R$. scabra), purple nutsedge (Cyperus rotundus), garden spurge (Chamaesyce birta), and cutleaf evening primrose (Oenothera laciniata). The pine bark + herbicide treatment resulted in lower weed coverage than any other treatment on eight evaluation dates throughout the study in shrub beds (Fig. 5) and on seven evaluation dates in groundcover beds (Fig. 6). Excluding the control plots, the herbicide plots in both the shrub and groundcover beds had the highest mean weed coverage on more evaluation dates than any other treatment. The herbicide treatment in the shrub beds had a higher mean weed coverage than any of the mulch or mulch + herbicide treatments at 6 weeks after the initial application, but had lower weed coverage ratings than mulchonly treatments at 4 weeks after the second application made in January. The third application made in May was generally less effective, and the herbicide treatment was similar to the pine bark treatment after 2 weeks and had higher weed coverage than either of the two mulch + herbicide treatments at that time. In groundcover beds, both mulch + herbicide treatments had weed coverage ratings that remained at or below $10 \%$ for $\approx 12$ weeks after the first application, 6 weeks after the second application, and 12 weeks after the third application. Although these plots did require weeding on certain dates during this time, the addition of herbicide did result in lower mean weed coverage ratings compared with the use of mulch alone, on most instances.

EFFECTS OF MULCH AND HERBICIDE USE ON WEEDING FREQUENCY AND TIME. In the Balm shrub and groundcover plots, there were no differences in weeding frequency between the herbicide plots and control plots. However, cumulative weeding time was significantly less for the herbicide plots when compared with the control plots, reducing total maintenance costs by $\approx 27 \%$ (Table 2 ). In Balm shrub plots, weeding frequencies were similar among herbicide, pine straw, pine straw + herbicide, and pine bark treatments. The only treatment that resulted in less weeding frequency than the herbicide treatment was pine bark + herbicide. When we analyzed the average cumulative weeding time, all treatments had resulted in decreased weeding time compared with the control plots. Pairwise comparisons showed that the four mulch and mulch + herbicide treatments resulted in similar weeding times and required less weeding time than the herbicide treatment level $(P<0.001)$. Weeding frequency and weeding time were similar when comparing the pine bark and pine straw treatments against the pine bark + herbicide $(P=0.573)$ and pine straw + herbicide treatments $(P=$ 0.583 ). Contrast statements showed that mulching (both types) had more of an impact on hand weeding frequency and time compared with herbicide. There was a significant difference when comparing the herbicide treatment to the two herbicide + mulch treatments $(P<0.001)$. In contrast, there was no difference when comparing the two mulch treatments to the two mulch + herbicide treatments $(P=0.075)$. Mulch type did not 


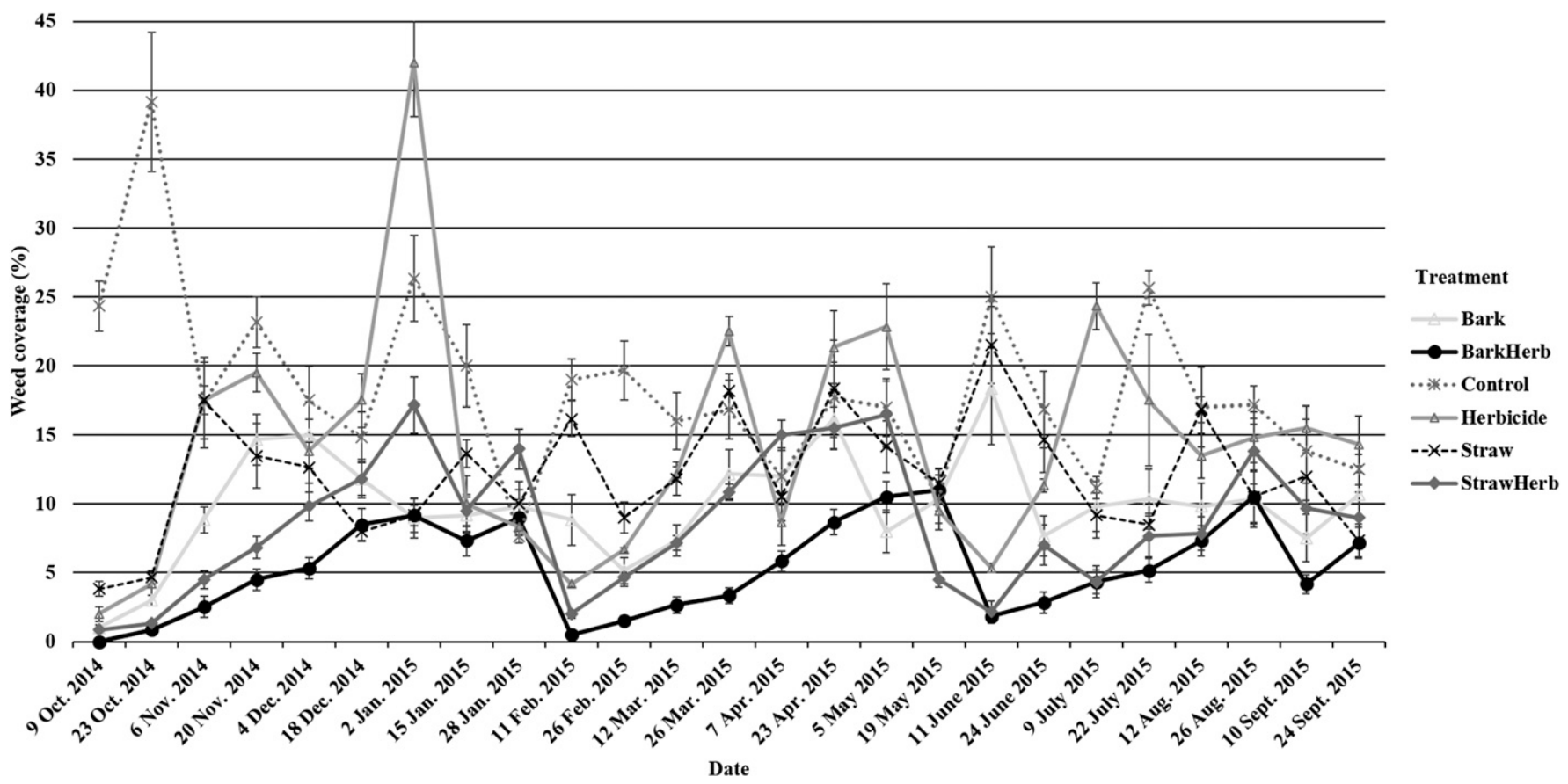

Fig. 6. Biweekly percent coverage ratings in Apopka, FL, groundcover (asiatic jasmine) planting beds. Means and associated standard errors are shown. Pine bark = pine bark nuggets $[2$-inch $(5.1 \mathrm{~cm})$ depth], Pine straw = pine straw [ $\mathrm{mix}$ of longleaf and slash pine needles (2-inch depth)], herbicide = trifluralin + isoxaben applied on 10 Sept. 2014, and 14 Jan., and 11 May 2015 using the highest recommended label rate $\left[5 \mathrm{lb} /\right.$ acre $\left(5.6 \mathrm{~kg} \cdot \mathrm{ha}^{-1}\right)$ a.i. $]$, bark herb $=$ pine bark + herbicide, straw herb $=$ pine straw + herbicide.

influence weeding frequency in shrub beds, but pine bark mulch, either with or without the addition of herbicide, resulted in lower weeding time in shrub beds. For the groundcover beds, pine bark mulch was associated with both lower weeding frequency and reduced weeding time.

Similar to the results in Balm, herbicide and control plots at the Apopka site required similar weeding frequencies, but cumulative weeding time was lower for the herbicide treatment, which resulted in a cost savings of $30 \%$ (Table 2 ). In the Apopka shrub plots, total required weeding time was lowest for pine bark + herbicide, pine bark, and pine straw + herbicide treatments. In the groundcover beds, pine bark + herbicide resulted in the lowest weeding frequency of any treatment. Although pine bark and pine straw were similar to the herbicide treatment in terms of weeding frequency, the four mulch and mulch + herbicide treatments resulted in lower weeding time than the herbicide treatment. In both bed types, mulch alone resulted in lower weeding frequency and time than herbicide. Although the addition of herbicide did not provide any added benefit in terms of weeding time or frequency in Balm, the two herbicide + mulch treatments required less frequent weeding and less weeding time than the two mulch treatments when applied without herbicide, reducing maintenance costs by $63 \%$ and $76 \%$ for pine bark and by $53 \%$ and $52 \%$ for pine straw in shrub and groundcover beds, respectively. When comparing mulch types, pine bark outperformed pine straw in shrub beds $(P=0.006)$, but there were no differences in weeding frequency or time between different mulch types in groundcover beds $(P=0.10)$.

EFFECTS OF HERBICIDE USE AND MULCH TYPE ON APPLICATION FREQUENCY. Pairwise comparisons show that neither mulch type $(P=$ $0.838)$ nor herbicide $(P=0.967)$ use had any impact on mulching frequency or time at the Balm location (Table 3). Pine bark treatments did, however, require a lower amount of mulch to maintain adequate depth in both bed types. There were no significant differences in mulch type when examining the time needed to reapply mulch.

In Apopka, there were no differences in mulching frequency between any treatment in shrub beds; however, the pine bark treatment required less frequent mulch addition compared with pine straw treatments in groundcover beds $(P<0.001)$. In shrub beds, the time needed to reapply mulch was the same for each mulch type regardless of whether herbicide was applied. In groundcover beds, the presence or absence of herbicide did not have an impact on total mulching time for either the pine bark or the pine straw treatments. However, on average, the pine bark and pine bark + herbicide treatments resulted in lower mulching times as compared with the pine straw and pine straw + herbicide treatments $(P<0.001)$. In general, the pine bark and pine bark + herbicide treatments at Apopka had lower mulching frequency, amount, and time compared with the pine straw and pine straw + herbicide treatments.

\section{Discussion}

Environmental conditions observed during the study were not significantly correlated with weed coverage or weeding time. As naturally occurring species were used to evaluate weed coverage, different species predominated during different times of the year and throughout a range of environmental conditions. 


\section{Research Reports}

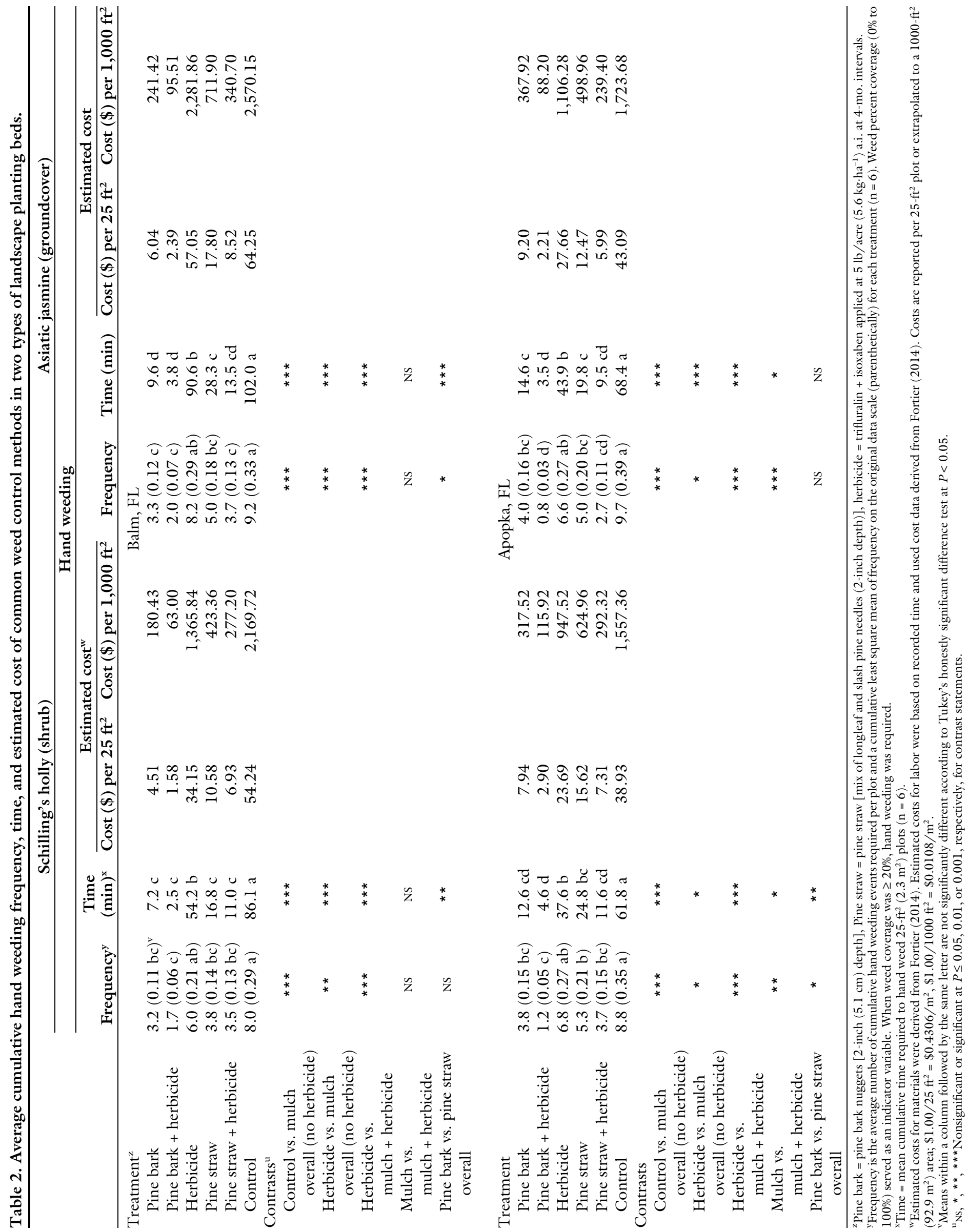




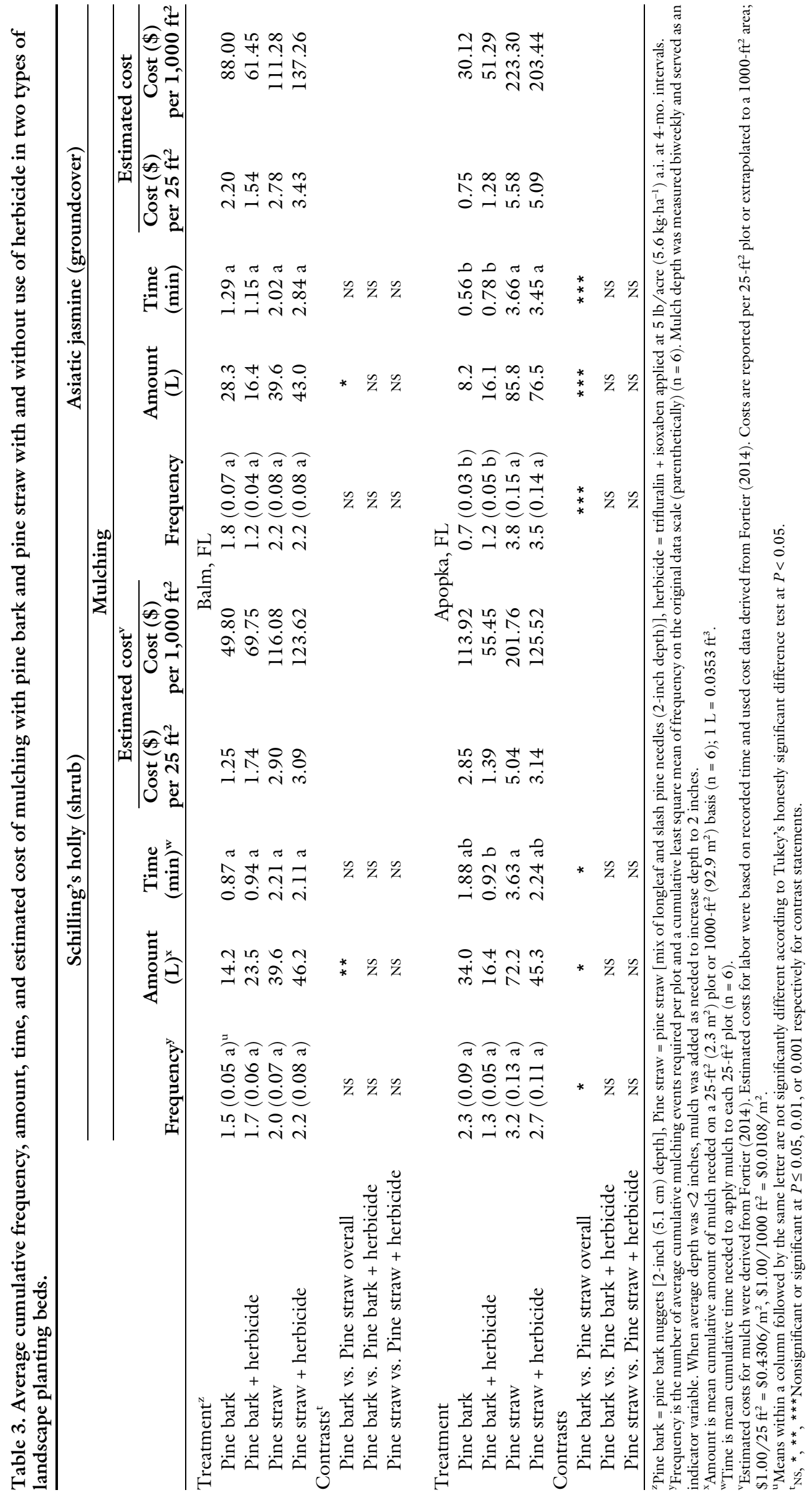


Weed coverage was more closely correlated with weeding time in Balm $\left(R^{2}=0.67\right)$ than in Apopka $\left(R^{2}=\right.$ $0.46)$, likely due to the weed species present. For example, in Apopka, two commonly observed species were tropical mexican clover and florida pusley. The prostrate growth pattern of these species caused high weed coverage ratings on several occasions, but because they have tap roots and do not root at the nodes or otherwise spread vegetatively (Wunderlin et al., 2016), hand weeding could be accomplished quickly and may have contributed to poor correlations between weed coverage and hand weeding time on certain data collection dates when these species predominated. Differences in weed species and weed pressure also contributed to greater variability in biweekly weed coverage ratings in Apopka compared with Balm where mean weed coverage ratings generally remained between $5 \%$ and $20 \%$ in both bed types (Figs. 3-6). Weed pressure was generally higher in Apopka as evidenced by weeding frequency needed in most treatments (Table 2). Further, the prevalence of certain species, such as spotted spurge, which have no dormancy requirement and germinate and grow quickly (Neal and Derr, 2005 ) also attributed to greater variability as their growth rate allowed them to cover a larger percentage of the plots in between biweekly evaluations.

Weeding times and frequency results were generally consistent at both locations and in both bed types. Pine bark and pine straw treatments both result in similar weeding frequency and time, the only exception being in groundcover beds in Balm in which pine bark reduced weeding time compared with pine straw. Similarly, within each mulch type, the addition of herbicide did not result in decreased weeding frequency or time, except for groundcover plots in Apopka where the pine bark + herbicide treatment was used. In all cases, use of herbicide alone did not reduce weeding frequency compared with nontreated plots, but it did reduce total weeding time.

Similar results have been reported in other cropping systems. The herbicide treatment reduced total weeding costs by $\approx 27 \%$ in Balm and $30 \%$ in Apopka, which is less than the $50 \%$ reduction in labor costs observed following applications of a preemergence herbicide application (napropamide) reported by Lanini and Le Strange (1994) in bell pepper (Capiscum annumm). The trifluralin + isoxaben granular herbicide was chosen because it has the most extensive labeling in terms of the number of ornamentals to which it can be applied, is widely used by professional pest management companies, and is available to homeowners without a pesticide applicator's license. However, it is not widely considered as being the most effective or broadspectrum herbicide available. Although use of an herbicide did provide a benefit in the absence of mulch in Balm and in both the presence and absence of mulch in Apopka, it is unclear how greatly this benefit may have been increased had a more limited, but perhaps more broad spectrum or effective herbicide been used.

Another trend that was observed at both locations and beds types was that the use of mulch alone provided better weed control (in terms of weeding time and frequency) compared with the use of herbicide alone. The addition of herbicide to mulch treatments provided no added benefit in Balm either within each mulch type or overall. In Apopka, the addition of herbicide did reduce weeding time and frequency in pine bark-treated groundcover beds and reduced both weeding time and frequency when evaluating both mulch types with or without the addition of herbicide overall. Froment et al. (2000) reported that chopped straw and wood chips applied at depths of 5 or $10 \mathrm{~cm}$ (2.0 or 3.9 inches) provided better weed control [specifically of common groundsel (Senecio vulgaris)] compared with an application of propyzamide + isoxaben. Other studies have shown the ability of various mulch materials to outperform herbicides when applied to non-mulched areas (Cahill et al., 2005). Research using the same herbicide active ingredients and similar rates evaluated in this study has shown similar weed control with pine bark nuggets or hardwood chips applied at depths of at least $3 \mathrm{~cm}(1.2$ inches) compared with herbicide applied alone (Somireddy, 2012). When mulches were applied at depths of at least $6 \mathrm{~cm}$ (2.4 inches), which were closer to the 2-inch depth used in the present study, mulch-only treatments outperformed the herbicide treatment. Somireddy (2012) also noted greater herbicide efficacy and longer persistence when applied in combination with mulch. Both isoxaben and trifluralin can be degraded by ultraviolet light, but trifluralin is much more susceptible (Senseman, 2007). The authors concluded that herbicide losses by photodegradation may have been minimized when applied in conjunction with a mulch, and increased efficacy could further be explained by the physical barrier provided by the mulch layer. Previous research has shown that as mulch depth increases, the benefits of herbicides used in combination with those mulches decrease due to increased light exclusion and the physical barrier provided by herbicides (Marble, 2015).

Overall, similar trends were observed in both bed types at both locations. The weed suppression potential of various groundcover species has been evaluated (Eom et al., 2005; Foo et al., 2011), but no previous reports have specifically addressed the ability of asiatic jasmine to suppress weed growth. Previous research has shown that once established, several groundcover species do significantly suppress weed growth (Foo et al., 2011). It was hypothesized that as the asiatic jasmine became more established, weed suppression would have increased due to shading and competitive effects. This effect was not readily evident in this trial, as data were only recorded for 1 year and jasmine plants did not have a chance to become fully established over the course of this trial. Consequently, weed growth was generally similar in both bed types or in the case of Balm, slightly higher in beds planted with asiatic jasmine in most instances. Another possible explanation for slightly greater weeding times in asiatic jasmine beds was that the growth habit made weeding more difficult in some cases. Future work would be needed to determine hand weeding times and frequency needed on fully established groundcover vs. shrub beds using various mulch and/or herbicide treatments.

Depths used in this study were based on common university and industry guidelines (Brown, 2014; Watson and Himelick, 2005) and 
are less than the higher depths of $\approx 7.6 \mathrm{~cm}$ (2.99 inches) or greater that have previously been reported to provide greater weed control (Cahill et al., 2005; Chalker-Scott, 2007; Froment et al., 2000; Somireddy, 2012). Maintaining a mulch depth of only 2 inches likely contributed to the herbicide having a greater impact on weeding frequency and time in Apopka. Further, some of the most prevalent weeds observed in Apopka also contributed to the herbicide having a greater impact. Spotted spurge, one of the most commonly observed species in Apopka during the summer months, is typically controlled by isoxaben or isoxaben-containing herbicides (Gallitano and Skroch, 1993; Judge et al., 2004). Further, trifluralin + isoxaben provides partial control or suppression of florida pusley when applied at rates used in this trial (Dow AgroSciences, 2010). The reason the herbicide had less of an impact in Balm is unclear, but is most likely due to differences in weed species present and their sensitivity to isoxaben and/or trifluralin.

Few differences were observed in mulching frequency, amount, and time. In Balm, pairwise comparisons showed no significant differences between mulching frequency or time when comparing pine bark or pine straw. The only difference that was observed was that pine bark treatments did require less mulch addition compared with pine straw treatments in both bed types. In Apopka shrub beds, the pine bark + herbicide treatment resulted is less mulching time compared with pine straw and pine straw + herbicide treatments, but mulching frequency was similar among all treatments. In groundcover beds, both pine bark treatments resulted in less mulching frequency and less mulching time compared with both pine straw treatments. Contrast statements showed that overall, use of pine bark resulted in less mulching frequency, amount, and time compared with use of pine straw, and this effect was more evident in groundcover beds compared with shrub beds.

Previous studies have examined the decomposition rates of various mulch materials (Singer and Martin, 2008; Valenzuela-Solano and Crohn, 2006). Duryea et al. (1999a) evaluated the decomposition rate of pine bark and pine straw, as well as other mulching materials, as a side-by-side comparison. Similar to results observed in this study, Duryea et al. (1999a) reported that after 1 year, pine straw needle mulch decreased in depth by 2 inches (3.5 to 1.5 inches), while pine bark mulch depth subsided $\approx 0.3$ inches over the same time frame. Although the use of pine bark as a mulch material did not significantly impact mulching frequency in Balm, pine bark beds required more mulch in Balm and increased mulching frequency and amount in Apopka due to differences in degradation rates of these materials. Use of herbicide had no impact on mulching amount within either mulch type in either bed type or location.

Results of this study suggests that use of pine bark or pine straw as mulching materials will provide greater weed and reduce overall costs compared with using herbicides alone if depth is maintained at least 2 inches. The use of pine bark generally resulted in better weed control (less weeding frequency and time) and less mulch was needed to maintain adequate depths, further reducing overall installation + maintenance costs $(\mathrm{Ta}-$ ble 4$)$. The addition of an herbicide to the mulch layer did improve weed control in Apopka but had little impact in Balm, suggesting that herbicide effectiveness will largely depend on the weed species present and the active ingredients applied. Cost data show that when considering estimates, while installation costs were generally similar between pine bark and pine straw (Table 1), use of pine bark + herbicides

Table 4. Estimated installation (labor + material) and annual maintenance (handweeding + mulch + herbicide) costs of common weed control methods in two types of landscape planting beds.

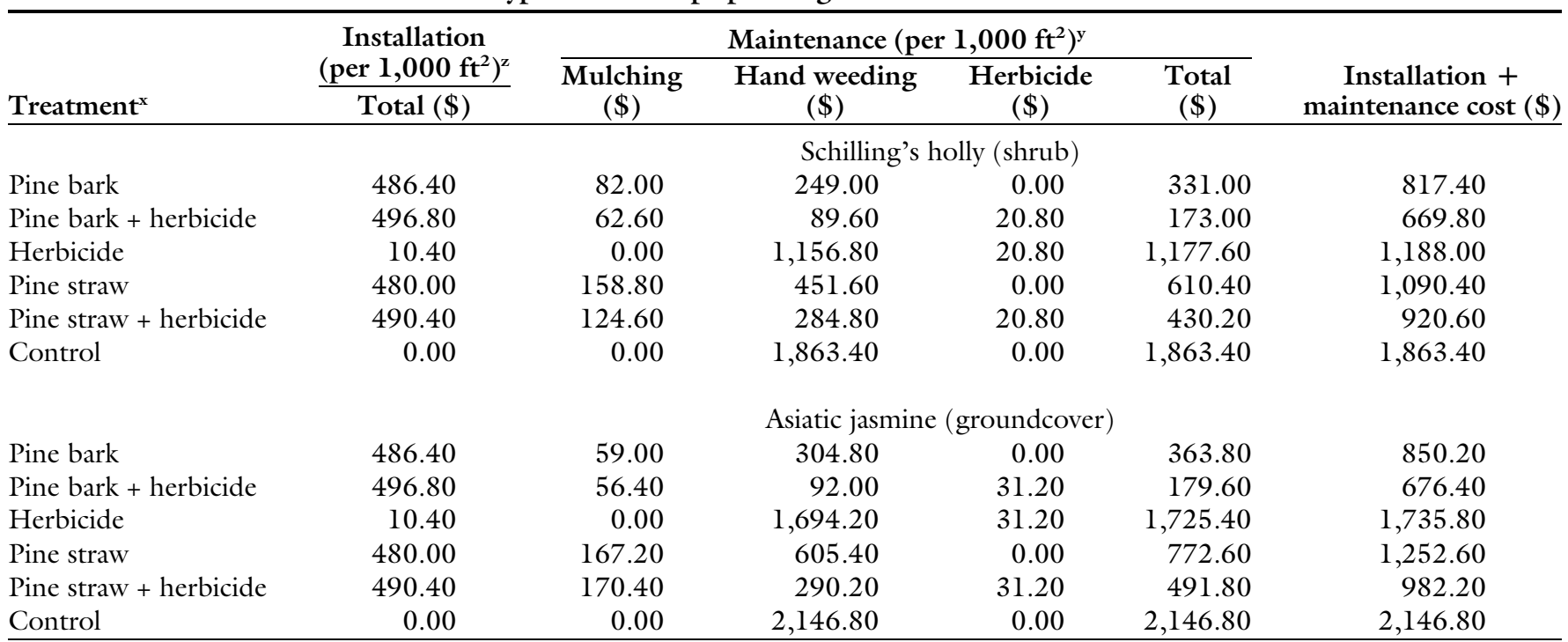

${ }^{\mathrm{z}}$ Material and labor costs derived from Fortier (2014). Herbicide cost based on average advertised price of trifluralin + isoxaben applied at $5 \mathrm{lb} / \mathrm{acre}\left(5.6 \mathrm{~kg} \cdot \mathrm{ha} \mathrm{f}^{-1}\right)$ a.i. ${ }^{\mathrm{y}}$ Estimated costs for materials were derived from Fortier (2014). Estimated costs for labor were based on mean recorded time of Apopka and Balm, FL sites and used cost data derived from Fortier (2014). Mulching and herbicide costs include labor + materials costs; $\$ 1.00 / 25 \mathrm{ft}^{2}\left(2.3 \mathrm{~m}^{2}\right)=\$ 0.4306 / \mathrm{m}^{2}, \$ 1.00 / 1000 \mathrm{ft}^{2}\left(92.9 \mathrm{~m}{ }^{2}\right)=\$ 0.0108 / \mathrm{m}^{2}$. ${ }^{\mathrm{x}}$ Pine bark $=$ pine bark nuggets $[2$-inch $(5.1 \mathrm{~cm})$ depth]; Pine straw $=$ pine straw $[$ mix of longleaf and slash pine needles $(2$-inch depth $)]$, herbicide $=$ trifluralin + isoxaben applied at $5 \mathrm{lb} /$ acre a.i. at 4 -mo. intervals. 
reduced weed control maintenance costs by $75 \%$ in Balm and $60 \%$ in Apopka across both bed types when compared with using pine straw + herbicide (Table 2). While in some cases differences were not observed in terms of weeding frequency or time when comparing mulch and mulch + herbicide treatments, the addition of trifluralin + isoxaben reduced weeding maintenance costs by $60 \%$ and $70 \%$ and $46 \%$ and $53 \%$ in pine bark and pine straw beds in Apopka and Balm, respectively ( $\mathrm{Ta}-$ ble 4 ). The use of pine bark as mulch reduced mulching costs by $45 \%$ in Balm and 67\% in Apopka across both bed types with and without the addition of an herbicide treatment.

It should be noted that many factors will affect the cost of weed control methods in landscape planting beds, and industry practices will depend on the individual companies' practices, sites, weed pressure, value of the landscape, or other contract agreements, and many other factors. In some cases, certain landscape maintenance companies may only hand weed around particularly sensitive ornamentals (e.g., bedding plants) or in cases where directed postemergence herbicide applications, such as glyphosate, cannot be made. As many different types of postemergence herbicides could be used to control weeds, and some such as imazaquin, bentazon, clopyralid, and graminicides are labeled for over-the-top application to certain ornamentals, evaluating postemergence herbicide use as a maintenance component was outside the scope of this study. Hand weeding frequencies may also differ depending on company practices. It is unclear how weeding frequency or hand weeding time would have differed if a higher or lower weed coverage was chosen as an indicator, but research has shown that more frequent hand weeding typically reduces overall costs (Lanini and Le Strange, 1994). Mulch addition may also only typically be added to a particular landscape at predetermined contracted intervals, such as twice per year, quarterly, etc. However, in these cases, mulch materials that have not degraded are typically not removed and mulch depths are likely to be inconsistent throughout areas where mulch is added.
The goal of this study was to examine two of the most commonly used mulch materials in Florida and the southeastern United States with or without the addition of an herbicide, and to estimate annual maintenance costs when consistent depths were maintained. Based on the results of this study, the use of largeparticle pine bark mulches likely will result in lower maintenance costs compared with pine straw due to decreased composition and improved weed control whether herbicides are used. Within each mulch type, the addition of herbicide did not significantly improve weed control in terms of reducing weeding frequency or weeding time. However, when considering total installation + maintenance costs averaged over the two sites, the addition of herbicide to pine bark or pine straw beds reduced total costs by $\approx 20 \%$ (Table 4). Other factors will also influence the best choice of mulch, including cost or availability in a particular area, delivery fees (which were not evaluated or included in this study), and aesthetic appeal or personal preference. Ornamental species present may also influence choice; for example, pine straw may be more suitable for landscapes containing pine trees (Pinus sp.), as natural needle drop will occur and contribute to existing mulch layers. Suitable mulch materials may also depend upon other pests that are common in a particular area, as differences have been reported for various mulch types in terms of attracting unwanted pests (Duryea et al., 1999b; Gill et al., 2011).

\section{Literature cited}

Appleton, B.L. and J.F. Derr. 1989. Combining mulch with geotextiles for landscape weed control. Proc. Southern Nursery Assn. Res. Conf. 34:262-265.

Brown, S.P. 2014. Checklist of Floridafriendly landscaping practices. 7 Sept. 2016. <http://edis.ifas.ufl.edu/ep4l3>.

Cahill, A., L. Chalker-Scott, and K. Ewing. 2005. Wood-chip mulch improves plant survival and establishment at no-maintenance restoration site (Washington). Ecol. Res. 23:212-213.

Chalker-Scott, L. 2007. Impact of mulches on landscape plants and the environment A review. J. Environ. Hort. 25:239-249.
Cochran, D.R., C.H. Gilliam, D.J. Eakes, G.R. Wehtje, P.R. Knight, and J. Olive. 2009. Mulch depth affects weed seed germination. J. Environ. Hort. 2:85-90.

Dow AgroSciences. 2010. Snapshot herbicide product label. Dow AgroSciences, Indianapolis, IN.

Duryea, M.L., R.J. English, and L.A. Hermansen. 1999a. A comparison of landscape mulches. J. Arboricult. 25:8897.

Duryea, M.L., J.B. Huffman, R.J. English, and W. Osbrink. 1999b. Will subterranean termites consume landscape mulches? J. Arboricult. 25:143-150.

Eom, S.H., A.F. Senesac, I. TsontakisBradley, and L.A. Weston. 2005. Evaluation of herbaceous perennials as weed suppressive groundcovers for use along roadsides or in landscapes. J. Environ. Hort. 23:198-203.

Florida Automated Weather Network. 2016. Archived weather data. 31 Oct. 2016. <http://fawn.ifas.ufl.edu/data/>

Foo, C.L., K.C. Harrington, and M.B. MacKay. 2011. Weed suppression by twelve ornamental groundcover species. N.Z. Plant Protection 64:149-154.

Fortier, R. 2014. Site work and landscape cost data. 34th ed. Robert S. Means Publ., Rockland, MA.

Froment, M.A., C.P. Britt, and J. Dooney. 2000. Farm woodland weed control: Mulches as an alternative to herbicides around newly planted oak Quercus robur transplants. Asp. Appl. Biol. 20:81-86.

Gallitano, L.B. and W.A. Skroch. 1993. Herbicide efficacy for production of container ornamentals. Weed Technol. 7:103111.

Gill, H.K., R. McSorley, and M. Branham. 2011. Effect of organic mulches on soil surface insects and other arthropods. Fla. Entomol. 94:226-232.

Greenly, K. and D. Rakow. 1995. The effects of mulch type and depth of weed and tree growth. J. Arboricult. 21:225232.

Horowitz, M. 1993. Couverture du sol pour la gestion des mauvaises herbes, $\mathrm{p}$. 149-154. In: J.M. Thomas (ed.). Maitrise des adventices par voie non chimique: Communications de la quatrieme conference international. 2 nd ed. Tholey-Theley, Saarland, Germany.

Judge, C.A., J.C. Neal, and J.B. Weber. 2004. Dose and concentration response of common nursery weeds to Gallery, Surflan, and Treflan. J. Environ. Hort. 22:106-112. 
Lanini, W.T. and M. Le Strange. 1994. Weed control economics in bell pepper (Capsicum annuum) with napropamide and hand weeding. Weed Technol. 8:530-535.

Littell, R.C., G.A. Milliken, W.W. Stroup, R.D. Wolfinger, and O. Schabenberger. 2006. SAS for mixed models. 2 nd ed. SAS Institute, Cary, NC.

Marble, S.C. 2015. Herbicide and mulch interactions: A review of the literature and implications for the landscape maintenance industry. Weed Technol. 29:341349.

Marble, S.C., A.K. Koeser, and G. Hasing. 2015a. A review of weed control practices in landscape planting beds: Part 1: Nonchemical methods. HortScience 50:851856.

Marble, S.C., A.K. Koeser, and G. Hasing. $2015 \mathrm{~b}$. A review of weed control practices in landscape planting beds: Part 2: Chemical methods. HortScience 50:857862 .
Martin, C., H. Ponder, and C. Gilliam. 1987. Ability of polypropylene fabrics to inhibit the growth of six weed species. Alabama Agr. Expt. Sta. Rpt. 5:25-26.

Neal, J.C. and J.F. Derr. 2005. Weeds of container nurseries in the United States. North Carolina Assn. Nurserymen, Raleigh, NC.

Richardson, B., C.H. Gilliam, G. Fain, and G. Wehtje. 2008. Container nursery weed control with pine bark mini-nuggets. J. Environ. Hort. 26:144-148.

Senseman, S.A. 2007. Herbicide handbook. 9th ed. Weed Sci. Soc. Amer., Lawrence, KS.

Singer, C.K. and C.A. Martin. 2008. Effect of landscape mulches on desert landscape microclimates. J. Arboricult. Urban For. 34:230-237.

Somireddy, U. 2012. Effect of herbicideorganic mulch combinations on weed control and herbicide persistence. PhD Diss., Ohio State Univ. 11 Aug. 2016. <https://etd.ohiolink.edu/rws_etd/ document/get/osul325255792/ inline $>$.

Teasdale, J.R. and C.L. Mohler. 2000. The quantitative relationship between weed emergence and the physical properties of mulches. Weed Sci. 48:385392.

Valenzuela-Solano, C. and D.M. Crohn. 2006. Are decomposition and $\mathrm{N}$ release from organic mulches determined mainly by the chemical composition? Soil Biol. Biochem. 38:377-384.

Watson, G. and E.B. Himelick. 2005. Best management practices: Tree planting. Intl. Soc. Arboricult., Champaign, IL.

Wesson, G. and P.F. Wareing. 1967. Light requirements of buried seed. $\mathrm{Na}$ ture 21:600-601.

Wunderlin, R.P., B.F. Hansen, A.R. Franck, and F.B. Essing. 2016. Atlas of Florida plants. 21 Sept. 2016. <http:// florida.plantatlas.usf.edu/>. 